\title{
The Impact of Foreign Direct Investment on Trade (Export and Import) in Turkey
}

\author{
Mehman Karimov \\ PhD, Kaposvár University, \\ Faculty of Economic Science
}

\section{Abstract}

It is said that after globalization processes foreign direct investment start to influence trade moreover it is very complicated to deduce the relationship between trade and FDI according to theoretical analysis. Therefore, empirical studies showed that until the 1980s international trade generated direct investment but after 1980s FDI started to heavily influencing international trade. Also, results showed that the relationship can differ from one country to another. Thus, this paper is aimed to analyze the impact of Foreign Direct Investment inflow on the macroeconomic variable as a Trade (Export, Import) in Turkey. The paper covers the time period from 1974 to 2017. The time series datasets, those are obtained from World Bank and IMF database are utilized in employed statistical models as ADF Unit Root, VAR lag selection, Johansen co-integration, and the Granger Causality tests, to fulfill empirical part of the paper. Based on results, it was confirmed that there was the presence of the co-integration between analyzed series. Additionally, results of Granger causality test showed that there is unidirectional causality from Export and Import to FDI.

Keywords: FDI, export, import, Turkey, ADF test, Johansen co-integration test, VAR, granger causality test

\section{Introduction}

Foreign Direct Investment is one of the important drivers of the economy in developing countries which brings to host countries the followings: finance, technologies, new management and etc. From past studies, it has been proved that they can cause economic growth, unemployment reduction, improvement of human capital and institutions in host countries, depending on the size of the market, level of human capital, infrastructure and economic stability of host country. With globalization processes foreign direct investment start to influence trade. Therefore, it is very complicated to deduce the relationship between trade and FDI according to 
theoretical analysis because the relationship between them can differ from one country to another(Fontagné, 1999).

Mostly, empirical studies showed that until the 1980s international trade generated direct investment but after 1980s FDI started to heavily influencing international trade(Fontagné, 1999).

The evidence from OECD studies indicates that foreign investment abroad stimulates the growth of exports from originating countries (investing countries) and, consequently, that this investment is complementary to trade. An analysis of 14 countries demonstrated that each dollar of outward FDI produces about two dollars' worth of additional exports (OECD).

Conversely, in host countries, short-term foreign investment most often tends to increase imports, whereas an increase in exports appears only in the longer term. However, in the short term, host countries enjoy many benefits from foreign investment (technology transfers, job creation, local subcontracting, etc.)(Fontagné, 1999).

Turkey was the 18th largest economy in the world; with a GDP of US\$851 billion and US $\$ 10,540$ per capita, in 2017. Trade is an important part of the economy: total trade in goods and services had54\% of a share of GDP in 2017; total export with $\$ 156$ billion had $24.84 \%$ of a share of GDP: total import with $\$ 233$ billion had $29.33 \%$ of a share of GDP $^{1}$ (See Graph 1).

\section{Graph 1: Trade Balance (Export, Import) of Turkey (share of GDP).}

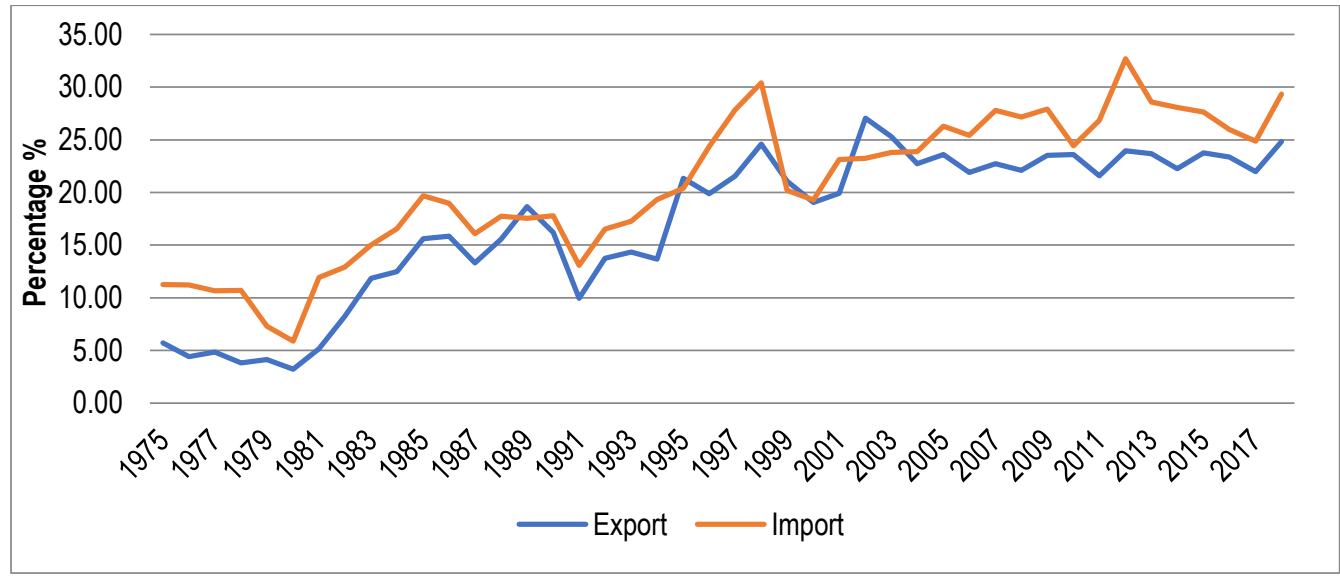

Source: Author`s own invention based on World Bank Database

According to the UNCTAD 2018 World Investment Report(UNCTAD, 2018), Turkey was the second largest recipient of FDI in West Asia, behind Israel. The crucial reasons 
of attraction the FDI were: strategic geographical location that makes Turkey be regional hub between Europe and Asia; the huge size of market that counts 70 million consumers; demographic vitality, the country has a developing young middle-class population with increased purchasing power and orientation towards consumption; the relative low cost labor with comparison EU market; establishment of European regulations and trade standards during repeated attempts to join European Union; attraction of FDI into services, electronics, shipbuilding, technology and telecommunications. The highest FDI flows which were detected were USD 22 billion in 2007, afterward it started to decrease to USD 13.3 billion FDI flows in 2017. The thought out reasons for dropping were: political stability, inflation, the weak currency and etc. (See Graph 2).

\section{Graph 2: FDI inflows into Turkey in the time period 1975-2017.}

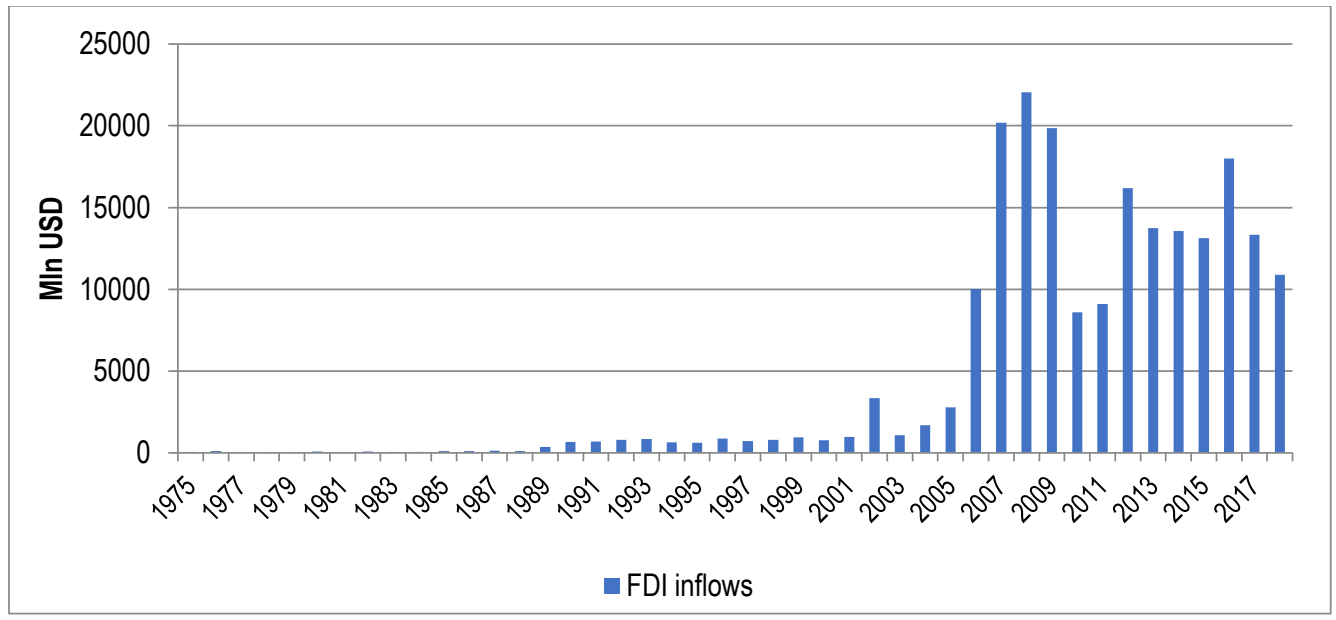

Source: Author`s own invention based on World Bank Database

Main partners of Turkey with FDI flows in 2017 were: Netherlands (23.8\%), Spain (19.5\%), Azerbaijan (13.6\%), Austria (4.4\%), UK (4.4\%), Germany (4\%), Japan (4\%), Belgium (3\%), and United States (2.3\%). The main invested sectors by foreign investors in 2017 were Finance and insurance (19.5\%), Transport and storage (18.2\%), Manufacturing (17\%), Energy (12.7\%) and Construction $(8.4 \%)^{1}$.

The main part of Turkey's exports are vehicles (15.2\%), machinery including computers $\$ 13.8$ billion (8.8\%), gems and precious metals $(6.9 \%)$, knit or crochet clothing, accessories (5.6\%), iron, steel (5.2\%) and electrical machinery, equipment (5.2\%). The majority of Turkey's imports contain raw materials and intermediate goods which feed into the production of higher value-added finished goods for export; the principal items being: mineral fuels including oil (15.9\%), machinery including

${ }^{1}$ Santander, Trade Portal, Turkey Foreign Direct Investment

https://en.portal.santandertrade.com/establish-overseas/turkey/foreign-investment 
computers (11.6\%), electrical machinery and equipment (9\%), gems and precious metals (7.5\%), vehicles (7.5\%), iron, steel (7.2\%) and plastics, plastic articles (5.7\%). Turkey continues to be a net exporter of services due to its significant surplus in travel services. Due to travel services Turkey is stable to be a net exporter of services. The main partners of Turkey in export are: Germany (9.6\%), United Kingdom (6.1\%), United Arab Emirates (5.9\%), Iraq (5.8\%), United States (5.5\%), Italy (5.4\%), France $(4.2 \%)$ and Spain (4\%). The main partners of Turkey in import are China (10\%), Germany (9.1\%), Russia (8.4), United States (5.1\%) and Italy $(4.8 \%)^{1}$.

The main objective of this paper to analyze the relationship between Foreign Direct Investment (FDI) and Trade (Export, Import).The content of paper will be structured as follows: In section 2 literature reviews will be expounded, in section 3 data description will be shown, in section 4 methodology will be disclosed, in section 5 empirical results from employed statistical analysis will be expounded, in section 6 conclusion will be described and finally in section 7 references will be shown.

\section{Literature Review}

\subsection{Theoretical studies}

The relationship between Foreign Direct Investment and Trade has recently been a remarkable topic for many studies in the literature review. Through theoretical studies, we will discuss horizontal and vertical FDI and their linkage with the New Trade Theory Approach. It is known that firms could either produce at home and export to foreign destinations or produce abroad and substitute home country exports with foreign affiliate local sales. Horizontal FDI refers to market seeking investments, in which the MNE duplicates the production and produces similar products or services in multiple locations. One of the key components in the horizontal FDI model, developed by (Markusen, 1984), is that firms choose to serve foreign markets through foreign affiliate local sales, instead of via exports. This is done in order to achieve better market access and reduce costs coming from tariffs and transportations. Thus, the reason for firms investing abroad can be concluded in a trade-off between the gains from being near the consumer and the losses originating from production dispersion, which is illustrated in the proximity-concentration hypothesis by (Brainard, 1997) (National Board of Trade, 2008).

Hence, in the horizontal FDI model, firms will prefer FDI instead of exports, to supply goods and services. This can be explained by the fact that the proximity gains from being located near the consumers are higher than the concentration gains, created from allocating the production in a single location. That is, FDI, arising with the purpose of achieving better market access will, in general, replace exports of final goods from the home country of final goods. A remark is due, however: Foreign

${ }^{1}$ Globaledge, Michigan State University, Turkey: Trade Statistics

https://globaledge.msu.edu/countries/turkey/tradestats 
production may also generate new export possibilities from the home country since imported inputs and parts may be exported to final production abroad (National Board of Trade, 2008).

Platform FDI can be seen as a more intricate form of horizontal FDI. Platform FDI refers to market-access driven investments, where the MNE locates production in a foreign country positioned in proximity to the export market, as a platform, in order to facilitate affiliate exports to that market. Therefore, platform FDI generates exports from foreign affiliates (National Board of Trade, 2008).

The importance and presence of this mode of FDI, which gives an additional explanation for why firms invest abroad, has been well documented in (Hanson, Mataloni Jr, \& Slaughter, 2005). In sum, horizontal FDI, which also includes platform FDI, explains why similar products are produced locally by MNEs in different parts of the world. The theory concludes that local production can increase sales volume by avoiding trade costs in exports. The theory further concludes that, in large markets with high incomes and a high willingness to pay, new investments in additional plants for local production and sales will be profitable, despite the extra investment costs. Thus, the theory of horizontal FDI explains why investments predominantly flow from rich countries to rich countries. Finally and most important, horizontal investments, made in order to increase market access, are likely to replace exports from the home country (National Board of Trade, 2008).

Vertical FDI refers to investments where the production process, or value chain, is fragmented into different parts in order to take advantage of differences in factor prices between countries or regions. That is, FDI where the prime motive is to obtain access to cheap production factors is labeled "Vertical FDI" in the literature. The vertical FDI model was first developed by (Helpman, 1984). In general, we can think of the organization of production and sales within MNEs as a production network, where different parts of the production process are located in different countries in order to take advantage of factor price differences (National Board of Trade, 2008).

This geographical dispersion of production will reduce production costs. Since different production stages require different intensities of skilled labor, and factor prices may differ across countries, it will be profitable to locate production stages which make intensive use of less-skilled labor in less developed countries (where less skilled labor is relatively abundant and Therefore, cheap). Likewise, activities which make intensive use of skilled labor, such as research and development (R\&D), are located where there are abundant resources of skilled labor in developed countries, making them relatively cheap there. Since vertical FDI implies a geographical separation of the production process, this type of FDI will initiate a trade through intra-firm trade in terms of exporting and importing intermediate goods from other parts of the firm (or from external suppliers) (National Board of Trade, 2008). 
Based on the OLI framework, the New Trade Theory Approach has been developed which incorporates location, ownership advantages, and internalization into general equilibrium models and predicts the pattern of trade. The market size, trade cost and differences in relative endowments of countries were included in location advantages. Knowledge-capital constitutes ownership advantage. According to location and ownership advantages, the location decision of MNEs is explained by two competing hypotheses: the proximity-concentration and the factor proportion hypothesis (Esiyok, 2010).

The factor proportion hypothesis views the phenomenon of FDI from the perspective of MNEs` ability to locate their different stages of production in different countries, considering the advantage of differences in factor costs (Markusen, 1984). For example, if firm-specific inputs (knowledge-capital) produced at headquarters could easily be transferred to the foreign affiliates at a low cost; a single plant multinational would arise to exploit possible factor cost differences. If factor propositions consideration dominates in a given industry, multinationals emerge in a single direction between countries. Then they export differentiated product back to the headquarters. The effect of this inter-industry trade on overall trade of given country depends on how MNEs in this country would meet the needs of production in terms of inputs, through import from the parent o a third country or local suppliers. Furthermore, external tariffs of regional blocs might affect the trade for inputs and induce MNEs to trade within the regional bloc (Esiyok, 2010).

Based on assumption that countries are symmetric in terms of market size, factor endowments and technological development, the proximity-concentration hypothesis (Brainard, 1993) suggest that firms prefer FDI over exporting provided that firms are motivated by proximity to customers or specialized suppliers at the expense of reduced scale. Therefore, MNEs' existence is positively correlated to high transport costs, trade barriers, low investment barriers and the ratio of scale economies at the plant level relative to corporate level (Brainard, 1993; Horstmann \& Markusen, 1992). Given the symmetries in countries' market size, factor endowments and technologies, MNEs motivated by market access would invest in foreign markets to minimize transport costs associated with exporting. This setting allows for horizontal FDI, where two-way investment between similar countries in terms of both absolute and relative factor endowment occurs (Esiyok, 2010).

Trade substituting effects of FDI is likely to dominate if MNEs are concerned with proximity. If proximity considerations dominate in a given industry, multinational sales would replace two-way trade in final goods of unequal magnitudes and might generate inter-industry trade in intermediates (Brainard, 1993). In this respect, even the presence of FDI itself might have further effects on trade between home and the host country, for instance, FDI stimulates demand for imports through informational spillovers and the creation of production channels (Swenson, 2004) (Esiyok, 2010). 
(Markusen, 1995, 1998; Markusen \& Venables, 1998; Markusen, Venables, Konan, \& Zhang, 1996) introduce asymmetries of market size, factor endowments and technological efficiency among countries in explaining the choice between countries in terms of market size, factor endowments, and technological efficiency, more firms would establish subsidiaries in these developing countries; hence FDI and trade could exist simultaneously. As a result, MNEs become more important relative to trade as countries become more similar in size relative endowments as world income grows, and multinational production would substitute trade when countries are similar (Brainard, 1997) (Esiyok, 2010).

(Markusen, 1998; Markusen et al., 1996) integrate the proximity-concentration hypothesis and factor proportion hypothesis in a knowledge-capital model, in which both vertical and horizontal FDI take place. The knowledge-capital framework combines the assumptions of proximity-concentration and factor proportion hypotheses with the assumption of investment liberalization (Esiyok, 2010).

\subsection{Empirical studies}

According to trade and foreign direct investment theories, those were mentioned above it can be accepted that there is link between them because export and import are one of the important factors of economy and it can be influenced by foreign direct investment actions. But still, it is a quite a complicated issue to find the relationship between them due to crucial factors that can influence this linkage between foreign direct investors and host countries. Furthermore, the empirical studies from literature gave various results according to user data and applied models. (Aizenman \& Noy, 2006) examined the intertemporal linkages between FDI and disaggregated measures of international trade for the time period 1980-1990. The applying Geweke (1982)'s decomposition method, they find that most of the linear feedback between trade and FDI (81\%) can be accounted for by Granger causality from FDI gross flows to trade openness (50\%) and from trade to FDI (31\%). The rest of the total linear feedback is attributable to simultaneous correlation between the two annual series. (Lin, 1995)examined trade effects of foreign direct investment (FDI) between Taiwan and each of the following four ASEAN countries: Indonesia, Malaysia, the Philippines, and Thailand. Regression results show that Taiwan's outward FDI has a significant positive effect on exports to and imports from the host country, whereas no such effects were consistently found for inward FDI from the same country. (Zhang, 2005) examined the relationship between FDI and export of China. The results showed that FDI indeed has had a positive impact on China's export performance, its exportpromoting effect is much greater than that of domestic capital, and its effect is larger in labor-intensive industries. (Simionescu, 2014) examined the relationship between trade and foreign direct investment G7 countries for the time period 2002-2013. The results obtained by the Granger causality tests for panel data showed that there is only short-run causality between FDI and exports and FDI and imports. There is unidirectional causal relationship on the long-run between FDI and trade. Moreover, 
short-run causality in both senses was observed for FDI and trade in G7 countries on the considered horizon. (Sharma \& Kaur, 2013) examined the causal relationships between FDI and trade (i.e Exports and Imports) in India and China for the time period 1976-2011. The results for China show unidirectional causality running from FDI to imports and FDI to exports, however, there exist bidirectional causality between imports and exports. India gives the results which are not similar to China where bidirectional causality between FDI and imports; FDI and exports; and exports and imports have been found.

\section{Data description}

The secondary time series dataset, which was obtained from the World Bank Database $^{1}$ for the period span from 1974 to 2017, was applied for analyses part of paper. These three variables were utilized in the model:

FDI -Foreign Direct Investment, net inflows (current USD)

EXP - Total export of goods and services (current USD)

IMP - Total import of goods and services (current USD)

\section{Methodology}

\subsection{Augmented Dickey-Fuller Unit Root Test}

The first step of the empirical analysis is the ADF test, which was developed by American statisticians David Dicker and Wayne Fuller (1979), to check the order of integration of the series to avoid spurious results. There are 3 various cases of the test equation²:

When the time series is flat (i.e. doesn't have a trend) and potentially slow-turning around zero, then use the following mathematical equation of test (1):

$\Delta \mathrm{z}_{\mathrm{t}}=\theta z_{t-1}+\alpha_{1} \Delta z_{t-1}+\alpha_{2} \Delta z_{t-2}+\ldots+\alpha_{p} \Delta z_{t-p}+\alpha_{t}$

Notice that this test equation does not have an intercept term or a time trend. The null hypothesis of the Augmented Dickey-Fuller t-test is $H_{0: \theta}=0$ (the data needs to be differenced to make it stationary). The alternative hypothesis is: $H_{1:} \theta^{<0}$ (the data is stationary and doesn't need to be differenced)

When the time series is flat and potentially slow-turning around a non-zero value, then use the following mathematical equation of test (2):

$\Delta \mathrm{z}_{\mathrm{t}}=\alpha_{0}+\theta z_{t-1}+\alpha_{1} \Delta z_{t-1}+\alpha_{2} \Delta z_{t-2}+\ldots+\alpha_{p} \Delta z_{t-p}+\alpha_{t}$

1World Bank Database

https://data.worldbank.org/country/turkey

${ }^{2}$ Southern Methodist University, Augmented Dickey Fuller Unit Root Test

http://faculty.smu.edu/tfomby/eco6375/BJ\%20Notes/ADF\%20Notes.pdf 
The null hypothesis of the Augmented Dickey-Fuller t-test is $H_{0}: \theta=0$ (the data needs to be differenced to make it stationary).The alternative hypothesis is: $H_{1}: \theta<0$ (the data is stationary and doesn't need to be differenced)

When the time series has a trend in it (either up or down) and is potentially slowturning around a trend line you would draw through the data then use following mathematical equation of test (3):

$\Delta \mathrm{z}_{\mathrm{t}}=\alpha_{0}+\theta z_{\mathrm{t}-1}+\gamma t+\alpha_{1} \Delta z_{t-1}+\alpha_{2} \Delta z_{t-2}+\ldots+\alpha_{p} \Delta z_{t-p}+\alpha_{t} \ldots . .$.

The null hypothesis of the Augmented Dickey-Fuller t-test is $H O: \theta=0$ (the data needs to be differenced to make it stationary). The alternative hypothesis is:HO: $\theta<0$ (the data is trend stationary and needs to be analyzed by means of using a time trend in the regression model instead of differencing the data).

When you have data that is exponentially trending then you might need to take the $\log$ of the data first before differencing it to avoid risk. To estimate the significance of the coefficients in focus, the modified T (Student)-statistic (known as Dickey-Fuller statistic) is computed and compared with the relevant critical value: if the test statistic is less than the critical value then the null hypothesis is rejected. Each version of the test has its own critical value which depends on the size of the sample1.

\subsection{VAR Optimal Lag length}

From past studies it is known that if wrong lag length is chosen for statistical analysis it could cause the over-fitting leads to a higher mean-square forecast error of the VAR and that under-fitting the lag length often produces auto-correlated errors. To avoid these risks VAR Optimal Lag Length has been applied to find correct lag length. The mathematical equation of test is ${ }^{2}(4)$ :

$\mathrm{y}_{\mathrm{t}}=v+\mathrm{A}_{1} \mathrm{y}_{\mathrm{t}-1}+\ldots+\mathrm{A}_{\mathrm{p}} \mathrm{y}_{\mathrm{t}-\mathrm{p}}+u_{t}$

Based on guideline, the most significant model is with the lowest Akaike Information Criterion (AIC).

\subsection{Johansen Co-integration test}

Johansen Co-integration test, which was developed by Johan Soren (1991), is statistical model to test co-integration between several series those are integrated in order $I(1)$ at $1^{\text {st }}$ difference. Johansen co-integration test contains trace and eigenvalue tests. The mathematical equation of test is ${ }^{3}(5)$ :

\footnotetext{
${ }^{1}$ RTMath, Mathematics experts in quantitative finance https://rtmath.net/help/html/93a7b7b9-e3c3-4f19-8a57-49c3938d607d.htm 2Universitat Wien, VAR Order Selection https://homepage.univie.ac.at/robert.kunst/pres07_var_abdgunyan.pdf 3IMF - International Monetary Fund, Testing for Co-integration Using the Johansen Methodology when Variables are Near-Integrated https://www.imf.org/external/pubs/ft/wp/2007/wp07141.pdf
} 
$\mathrm{y}_{\mathrm{t}}=\mu+\mathrm{A}_{1} \mathrm{y}_{\mathrm{t}-1}+\cdots+\mathrm{A}_{\mathrm{p}} \mathrm{y}_{\mathrm{t}-\mathrm{p}}+\varepsilon_{\mathrm{t}}$

The null hypothesis for test is: $\mathrm{H}_{0}=$ there is no co-integration between analyzed series. An alternative hypothesis is: $\mathrm{H}_{1}=$ there is at most 1 co-integration between analyzed series. Null hypothesis will be accepted if p-value $>0.05$.

\subsection{Granger Causality Test}

Granger causality, which was developed by British statistician Sir Clive William John Granger (1969), is a statistical concept of causality that is based on prediction. According to Granger causality, if a signal X1"Granger-causes" (or "G-causes") a signal X2, then past values of X1 should contain information that helps predict X2 above and beyond the information contained in past values of X2 alone ${ }^{1}$. The mathematical equation of test is (6):

$\mathrm{y}_{\mathrm{t}}=\alpha_{0}+\alpha_{1} \mathrm{y}_{\mathrm{t}-1}+\alpha_{2} \mathrm{y}_{\mathrm{t}-2}+\ldots+\alpha_{\mathrm{m}} \mathrm{y}_{\mathrm{t}-\mathrm{m}}+$ error $_{\mathrm{t}}$

The null hypothesis for model is: $\mathrm{H}_{0}=\mathrm{X}$ doesn't Granger Cause $\mathrm{Y}, \mathrm{Y}$ doesn 't Granger Cause X. Null hypothesizes will be accepted if $\mathrm{p}$-values is more than 0.05 .

\section{Empirical Results}

\subsection{Augmented Dickey-Fuller Unit Root Test}

As the pre-condition of Johansen co-integration test proposes, selected time-series must be non-stationary at a level and stationary at the 1st difference. Thus, the ADF test individually has been performed on the variables. According to the result of ADF test, the null hypothesis that series has a unit root at levels should be accepted, because T-statistics are less than critical values at $1 \%$ and $5 \%$ level of significance and P-values of variables are more than 0.05 . Thus, after taking the first difference, the series became stationary according to these outputs: T-statistics more than critical values at $1 \%$ and $5 \%$ level of significance and P-values less than 0.05 . Based on results, the null hypothesizes that series have unit root at $1^{\text {st }}$ difference should be rejected. Thus, ADF results showed that the observed series appeared to be integrated of order one (I (1)) (See Table 1).

\section{Table1: Augmented Dickey Fuller unit root test results}

\begin{tabular}{|c|c|c|c|c|c|}
\hline \multicolumn{6}{|c|}{ Null Hypothesis: (lnEXP) has a unit root } \\
\hline Variables & $\begin{array}{l}\text { ADF Test } \\
\text { Statistic }\end{array}$ & $\begin{array}{l}\text { Leve } \\
\text { l }\end{array}$ & $\begin{array}{l}\text { Critical } \\
\text { values }\end{array}$ & Prob* & $\begin{array}{l}\text { Conclusio } \\
\mathrm{n}\end{array}$ \\
\hline \multirow{3}{*}{$\begin{array}{l}\text { Export of goods and } \\
\text { services in current USD } \\
\text { at level: (lnEXP) }\end{array}$} & - & $1 \%$ & -3.592462 & \multirow{3}{*}{$\begin{array}{l}0.429 \\
2\end{array}$} & \multirow{3}{*}{$\begin{array}{l}\text { Non- } \\
\text { stationary }\end{array}$} \\
\hline & \multirow{2}{*}{$\begin{array}{l}1.68961 \\
5\end{array}$} & $5 \%$ & -2.931404 & & \\
\hline & & $10 \%$ & -2.603944 & & \\
\hline
\end{tabular}

${ }^{1}$ Scholarpedia, Granger Causality

http://www.scholarpedia.org/article/Granger_causality 


\begin{tabular}{|c|c|c|c|c|c|}
\hline \multicolumn{6}{|c|}{ Null Hypothesis: D(lnEXP) has a unit root } \\
\hline \multirow{3}{*}{$\begin{array}{l}\text { Export of goods and } \\
\text { services in current USD } \\
\text { at 1st difference: } \\
\text { (lnEXP) }\end{array}$} & \multirow{3}{*}{$\begin{array}{l}- \\
6.18446 \\
9\end{array}$} & $1 \%$ & -3.596616 & \multirow{3}{*}{$\begin{array}{l}0.000 \\
0\end{array}$} & \multirow[t]{3}{*}{ Stationary } \\
\hline & & $5 \%$ & -2.933158 & & \\
\hline & & $10 \%$ & -2.604867 & & \\
\hline \multicolumn{6}{|c|}{ Null Hypothesis: (lnIMP) has a unit root } \\
\hline \multirow{3}{*}{$\begin{array}{l}\text { Import of goods and } \\
\text { services in current USD } \\
\text { at level: (lnIMP) }\end{array}$} & \multirow{3}{*}{$\begin{array}{l}- \\
- \\
0.97699 \\
4\end{array}$} & $1 \%$ & -3.592462 & \multirow{3}{*}{$\begin{array}{l}0.753 \\
1\end{array}$} & \multirow{3}{*}{$\begin{array}{l}\text { Non- } \\
\text { stationary }\end{array}$} \\
\hline & & $5 \%$ & -2.931404 & & \\
\hline & & $10 \%$ & -2.603944 & & \\
\hline \multicolumn{6}{|c|}{ Null Hypothesis: D(lnIMP) has a unit root } \\
\hline Import of goods and & - & $1 \%$ & -3.596616 & \multirow{3}{*}{$\begin{array}{l}0.000 \\
0\end{array}$} & \multirow[t]{3}{*}{ Stationary } \\
\hline services in current USD & 7.43596 & $5 \%$ & -2.933158 & & \\
\hline $\begin{array}{l}\text { at 1st difference: } \\
\text { (lnIMP) }\end{array}$ & 3 & $10 \%$ & -2.604867 & & \\
\hline \multicolumn{6}{|c|}{ Null Hypothesis: (lnFDI) has a unit root } \\
\hline Foreign Direct & - & $1 \%$ & -3.592462 & \multirow{3}{*}{$\begin{array}{l}0.724 \\
5\end{array}$} & \multirow{3}{*}{$\begin{array}{l}\text { Non- } \\
\text { stationary }\end{array}$} \\
\hline Investment at level: & 1.05568 & $5 \%$ & -2.931404 & & \\
\hline$(\operatorname{lnFDI})$ & 2 & $10 \%$ & -2.603944 & & \\
\hline \multicolumn{6}{|c|}{ Null Hypothesis: D(lnFDI) has a unit root } \\
\hline Foreign Direct & - & $1 \%$ & -3.596616 & \multirow{3}{*}{$\begin{array}{l}0.000 \\
0\end{array}$} & \multirow[t]{3}{*}{ Stationary } \\
\hline Investment at 1 st & 9.30899 & $5 \%$ & -2.933158 & & \\
\hline difference: (lnFDI) & 0 & $10 \%$ & -2.604867 & & \\
\hline
\end{tabular}

Source: Author`s own calculations

\subsection{VAR Optimal Lag length}

According to (Lütkepohl, 1993) study, the over-fitting leads to a higher mean-square forecast error of the VAR and that under-fitting the lag length often produces autocorrelated errors. The results gained by (Braun \& Mittnik, 1993)show that approximates of a VAR, whose lag length varies from the true lag length are erratic. To avoid these risks VAR Lag Order Selection Criterion model was applied to find the optimal lag. According to the guideline, the best model is with the lowest Akaike Information Criterion (AIC). Based on results gained from the model the optimal lag for LnEXP, LnIMP and LnFDI are 1 (See Table 2, 3).

\section{Table2: Optimal Lag Selection model for LnEXP and LnFDI}

VAR Lag Order Selection Criteria, Endogenous variables: LnEXP LnFDI, Exogenous variables: C, Sample: 1974 2017, Included observations: 40
Lag LogL
LR
FPE
AIC
SC
HQ 


$\begin{array}{lllllll}0 & -100.0620 & \text { NA } & 0.564038 & 5.103099 & 5.187543 & 5.133631 \\ 1 & 1.340947 & 187.5954^{*} & 0.004330^{*} & 0.232953^{*} & 0.486285^{*} & 0.324549^{*} \\ 2 & 2.030792 & 1.207228 & 0.005120 & 0.398460 & 0.820680 & 0.551122 \\ 3 & 4.817945 & 4.598802 & 0.005465 & 0.459103 & 1.050211 & 0.672829 \\ 4 & 9.646993 & 7.485025 & 0.005287 & 0.417650 & 1.177646 & 0.692441\end{array}$

* indicates lag order selected by the criterion

LR: sequential modified LR test statistic (each test at 5\% level)

FPE: Final prediction error

AIC: Akaike information criterion

SC: Schwarz information criterion

HQ: Hannan-Quinn information criterion

Source: Author`s own calculations

Table3: Optimal Lag Selection model for LnIMP and LnFDI

VAR Lag Order Selection Criteria Endogenous variables: LnIMP LnFDI, Exogenous variables: C, Sample: 1974 2017, Included observations: 40

\begin{tabular}{lllllll}
\hline \hline Lag & LogL & LR & FPE & AIC & SC & HQ \\
\hline \hline & & & & & & \\
0 & -97.43903 & NA & 0.494711 & 4.971952 & 5.056396 & 5.002484 \\
1 & -15.45336 & $151.6735^{*}$ & $0.010027^{*}$ & $1.072668^{*}$ & $1.326000^{*}$ & $1.164265^{*}$ \\
2 & -13.59236 & 3.256748 & 0.011181 & 1.179618 & 1.601838 & 1.332279 \\
3 & -11.71014 & 3.105660 & 0.012488 & 1.285507 & 1.876615 & 1.499233 \\
4 & -11.02202 & 1.066582 & 0.014861 & 1.451101 & 2.211097 & 1.725892 \\
\hline \hline
\end{tabular}

* indicates lag order selected by the criterion

LR: sequential modified LR test statistic (each test at 5\% level)

FPE: Final prediction error

AIC: Akaike information criterion

SC: Schwarz information criterion

HQ: Hannan-Quinn information criterion

Source: Author`s own calculations 


\subsection{Johansen Co-integration test}

Based on the ADF unit root test our series are integrated of the same order, I(1) which means the Johansen co-integration test has been allowed to perform. Johansen cointegration test has been employed for LnEXP and LnFDI to analyze the long-run relationship between them. According to the obtained Johansen co-integration test results, those based on trace test and maximum eigenvalue test (p-values in both tests $=0.0054$ and $0.0037<0.05$ ), the null hypothesis is that there is no co-integration between LnIMP and LnFDI has been rejected. It has been confirmed that there is at most 1 co-integration between analyzed series ( $p$-values in both tests $=0.5480>0.05$ ) (See Table 4).

\section{Table4: Johansen Co-integration test for LnEXP and LnFDI}

\begin{tabular}{|c|c|c|c|c|}
\hline \multirow{2}{*}{\multicolumn{5}{|c|}{$\begin{array}{l}\text { Johansen Co-integration test: Sample (adjusted): } \\
\text { LnEXP, LnFDI, Lags interval (in first differences) } \\
\text { Unrestricted Co-integration Rank Test (Trace) }\end{array}$}} \\
\hline & & & & \\
\hline \multirow{3}{*}{$\begin{array}{l}\text { Hypothesized No. of } \\
\text { CE(s) } \\
\text { None* }\end{array}$} & \multirow{3}{*}{$\begin{array}{l}\text { Eigenvalue } \\
0.338876\end{array}$} & \multirow{3}{*}{$\begin{array}{l}\text { Trace } \\
\text { Statistic } \\
17.86794\end{array}$} & \multirow{3}{*}{$\begin{array}{l}0.05 \text { Critical } \\
\text { Value } \\
12.32090\end{array}$} & \multirow[t]{2}{*}{ Prob. } \\
\hline & & & & \\
\hline & & & & \\
\hline \multirow{3}{*}{ At most 1} & \multirow{3}{*}{0.011546} & \multirow{3}{*}{0.487753} & \multirow{3}{*}{4.129906} & $\begin{array}{l}0.005 \\
4\end{array}$ \\
\hline & & & & \\
\hline & & & & $\begin{array}{l}0.548 \\
0 \\
\end{array}$ \\
\hline \multicolumn{5}{|c|}{ Unrestricted Co-integration Rank Test (Maximum Eigenvalue) } \\
\hline $\begin{array}{l}\text { Hypothesized No. of } \\
\text { CE(s) }\end{array}$ & Eigenvalue & $\begin{array}{l}\text { Trace } \\
\text { Statistic }\end{array}$ & $\begin{array}{l}0.05 \text { Critical } \\
\text { Value }\end{array}$ & Prob. \\
\hline \multirow[b]{2}{*}{ At most 1} & \multirow[b]{2}{*}{0.011546} & \multirow[b]{2}{*}{0.487753} & \multirow[b]{2}{*}{4.129906} & $\begin{array}{l}0.003 \\
7\end{array}$ \\
\hline & & & & $\begin{array}{l}0.548 \\
0\end{array}$ \\
\hline
\end{tabular}

Trace test indicates 1 co-integrating eqn(s) at the 0.05 level, Max-eigenvalue test indicates 1 co-integrating eqn(s) at the 0.05 level

* denotes rejection of the hypothesis at the 0.05 level ** MacKinnon-Haug-Michelis (1999) p-values

Source: Author`s own calculations

Johansen co-integration test was employed for LnIMP and LnFDI to analyze the longrun relationship between them. According to the obtained Johansen co-integration test results, those based on trace test and maximum eigenvalue test(p-values in both tests $=0.0029$ and $0.0018<0.05$ ) the null hypothesis is that there is no co-integration between LnIMP and LnFDI, has been rejected. It has been found that there is at most 
1 co-integration between analyzed series ( $p$-values in both tests $=0.5449>0.05$ ) (See Table 5).

\section{Table 5: Johansen Co-integration test for LnIMP and LnFDI}

\begin{tabular}{|c|c|c|c|c|}
\hline \multirow{2}{*}{\multicolumn{5}{|c|}{$\begin{array}{l}\text { Johansen Co-integration test: Sample (adjusted) } \\
\text { LnIMP, LnFDI, Lags interval (in first differences } \\
\text { Unrestricted Co-integration Rank Test (Trace) }\end{array}$}} \\
\hline & & & & \\
\hline $\begin{array}{l}\text { Hypothesized No. of } \\
\text { CE(s) }\end{array}$ & Eigenvalue & $\begin{array}{l}\text { Trace } \\
\text { Statistic }\end{array}$ & $\begin{array}{l}0.05 \text { Critical } \\
\text { Value }\end{array}$ & Prob. \\
\hline None* & 0.418770 & 23.15609 & 15.49471 & $\begin{array}{l}0.002 \\
9\end{array}$ \\
\hline At most 1 & 0.008688 & 0.366504 & 3.841466 & $\begin{array}{l}0.544 \\
9\end{array}$ \\
\hline \multicolumn{5}{|c|}{ Unrestricted Co-integration Rank Test (Maximum Eigenvalue) } \\
\hline $\begin{array}{l}\text { Hypothesized No. of } \\
\mathrm{CE}(\mathrm{s})\end{array}$ & Eigenvalue & $\begin{array}{l}\text { Trace } \\
\text { Statistic }\end{array}$ & $\begin{array}{l}0.05 \text { Critical } \\
\text { Value }\end{array}$ & Prob. \\
\hline None* & 0.418770 & 22.78959 & 14.26460 & $\begin{array}{l}0.001 \\
8\end{array}$ \\
\hline At most 1 & 0.008688 & 0.366504 & 3.841466 & $\begin{array}{l}0.544 \\
9\end{array}$ \\
\hline
\end{tabular}

Trace test indicates 1 co-integrating eqn(s) at the 0.05 level, Max-eigenvalue test indicates 1 co-integrating eqn(s) at the 0.05 level

* denotes rejection of the hypothesis at the 0.05 level **MacKinnon-Haug-Michelis (1999) p-values

Source: Author`s own calculations

\subsection{Granger Causality test}

As mentioned previously, causal relationship will be checked between EXP and FDI through the Granger Causality test. The null hypothesis of the test, states the following:

$H_{0}$ : LnFDI does not Granger Cause LnEXP, and

$H_{0}$ : LnEXP does not Granger Cause LnFDI

Null hypothesis will be rejected if the probability value is less than $0.05 \%$.

\section{Table 6: Granger Causality test for LnEXP and LnFDI}

\begin{tabular}{lll}
\hline Pairwise Granger causality test, Lags 2, Sample 1974-2017 & & \\
\hline Null Hypothesis & F-statistic & Prob. \\
LnFDI does not Granger Cause LnEXP & 0.00434 & 0.9478 \\
LnEXP does not Granger Cause LnFDI & 20.7306 & $5 . E-05$ \\
\hline
\end{tabular}

Source: Author`s own calculations

According to the obtained results, from Granger causality test, the null hypothesis of no causal relationship from FDI to EXP should be accepted (P-value $=0.9478>0.05$ ). But based on P-value $=5 . E-05<0.05 \%$, the second null hypothesis of no causal relationship 
from EXP to FDI should be rejected. Thus, the results of the causality test demonstrated the unidirectional causal relationship from EXP to FDI (See Table 6).

The next step to check the causal relationship between IMP and FDI through Granger Causality test. The null hypothesis of the test states the following:

$H_{0}$ : LnFDI does not Granger Cause LnIMP, and

$H_{0}$ : LnIMP does not Granger Cause LnFDI

Null hypothesis will be rejected if the probability value is less than $0.05 \%$.

\section{Table 7: Granger Causality test for LnIMP and LnFDI}

\begin{tabular}{lll}
\hline \multicolumn{2}{l}{ Pairwise Granger causality test, Lags 2, Sample 1974-2017 } & \\
\hline Null Hypothesis & F-statistic & Prob. \\
LnFDI does not Granger Cause LnIMP & 3.55887 & 0.0665 \\
LnIMP does not Granger Cause LnFDI & 20.1379 & $6 . E-05$ \\
\hline
\end{tabular}

Source: Author`s own calculations

According to the obtained results from the Granger causality test, the null hypothesis of no causal relationship from FDI to IMP should be accepted (P-value $=0.0665>0.05$ ). But based on P-value $=6 . \mathrm{E}-05<0.05 \%$, the second null hypothesis of no causal relationship from IMP to FDI should be rejected. Thus, the results of the causality test demonstrated the unidirectional causal relationship from IMP to FDI (See Table 7).

\section{Conclusion}

The aim of the study was to analyze the relationship between Foreign Direct Investment inflows and Trade (Export, Import) in Turkey by using annual time series data for the period span from 1974 to 2017. It is known that depends on circumstances FDI can influence the import and export of host country and can't. If FDI uses local raw materials, and human capital and etc., then, they won't have any significant and positive impact on the import of host countries. In versus, if they will transfer machinery, equipment, raw materials, human capital, assets and etc., afterward they will have a significant positive impact on the import of host country.

The export can be stimulated by inward FDI from domestic sectors through spill-over effects. It builds strong demand incentives for domestic investors and stimulates export. Additionally, export-oriented FDI is able to create products that further will boost export of host country. Furthermore, export-led growth can be brought as an example because it will increase growth in productivity. Thus, productivity growth will enhance the competitiveness of products at the international level in the case of price and quality and by that raises its export.

The empirical findings showed us further; according to obtained results from Augmented Dickey-Fuller Unit Root Test, all series were non-stationary at levels and stationary at 1 st difference which is preconditions of the Johansen co-integration test. Based on obtained results from VAR optimal lag length test, 1 lag was chosen as an 
optimal lag for those series. The next step was the Johansen co-integration tests to see those series are co-integrated or not. Johansen co-integration test confirmed the existence of at most one long-run co-integration vector between EXP/IMP and FDI. The Granger Causality test was employed as a final step of the statistical analysis. Based on results there were unidirectional causal relationships from EXP to FDI and from IMP to FDI. Thus, according to the facts from theories and obtained empirical results, FDI has a positive linkage with Trade in Turkey. The lack of raw materials, management, technologies, and finance can be considered as consequences of the positive impact of FDI on the import of goods and services. Moreover, there is no doubt that the horizontal (market seeking) FDI implements investments in Turkey. Therefore, based on theories horizontal FDI manufactures products by using imported goods and services and afterward these created final products can be exported to international market. Thus, this empirical study can be the attempt to prove these above-mentioned claims.

\section{References}

[1] Aizenman, J., \& Noy, I. (2006). FDI and trade-Two-way linkages? The Quarterly Review of Economics and Finance, 46(3), 317-337.

[2] Brainard, S. L. (1993). An Empirical Assessment of the ProximityConcentration Tradeoff between Multinational Sales and Trade (No. w4580). Cambridge, MA: National Bureau of Economic Research. https://doi.org/10.3386/w4580

[3] Brainard, S. L. (1997). An Empirical Assessment of the ProximityConcentration Trade-off between Multinational Sales and Trade. American Economic Review, 87(4), 520-544.

[4] Braun, P. A., \& Mittnik, S. (1993). Misspecifications in vector autoregressions and their effects on impulse responses and variance decompositions. Journal of Econometrics, 59(3), 319-341. https://doi.org/10.1016/03044076(93)90029-5

[5] Esiyok, B. (2010). The Determinants of Foreign Direct Investment in Turkey: An Empirical Analysis, 207.

[6] Fontagné, L. (1999). Foreign Direct Investment and International Trade: Complements or Substitutes? OECD Science, Technology, and Industry. Working Papers 1999/03, OECD Publishing. http://dx. doi. org/10.1787 ....

[7] Hanson, G. H., Mataloni Jr, R. J., \& Slaughter, M. J. (2005). Vertical production networks in multinational firms. Review of Economics and Statistics, 87(4), 664-678.

[8] Helpman, E. (1984). A simple theory of international trade with multinational corporations. Journal of Political Economy, 92(3), 451-471.

[9] Horstmann, I., \& Markusen, J. (1992). Endogenous market structures in international trade (natura facit saltum). Journal of International Economics, 32(1-2), 109-129. 
[10]Lin, A. (1995). Trade effects of foreign direct investment: Evidence for Taiwan with four ASEAN countries. Review of World Economics, 131(4), 737-747. https://doi.org/10.1007/BF02707939

[11]Lütkepohl, H. (1993). Testing for Causation Between Two Variables in Higher-Dimensional VAR Models. In H. Schneeweiß \& K. F. Zimmermann (Eds.), Studies in Applied Econometrics (pp. 75-91). Physica-Verlag HD.

[12] Markusen, J. R. (1984). Multinationals, multi-plant economies, and the gains from trade. Journal of International Economics, 16(3-4), 205-226.

[13] Markusen, J. R. (1995). The boundaries of multinational enterprises and the theory of international trade. Journal of Economic Perspectives, 9(2), 169189.

[14] Markusen, J. R. (1998). Multinational firms, location and trade. World Economy, 21(6), 733-756.

[15] Markusen, J. R., \& Venables, A. J. (1998). Multinational firms and the new trade theory. Journal of International Economics, 46(2), 183-203.

[16] Markusen, J. R., Venables, A. J., Konan, D. E., \& Zhang, K. H. (1996). A unified treatment of horizontal direct investment, vertical direct investment, and the pattern of trade in goods and services. National Bureau of Economic Research.

[17] National Board of Trade. (2008). The relationship between international trade and foreign direct investments for Swedish multinational enterprises - Kommerskollegium. Retrieved February 22, 2019, from https://www.kommers.se/In-English/Publications/2010-and-older/Therelationship-between-international-trade-and-foreign-direct-investmentsfor-Swedish-multinational-enterprises/

[18] Sharma, R., \& Kaur, M. (2013). Causal links between foreign direct investments and Trade: A Comparative study of India and China. Eurasian Journal of Business and Economics, 6(11), 75-91.

[19] Simionescu, M. (2014). The Relationship between Trade and Foreign Direct Investment in G7 Countries a Panel Data Approach. Journal of Economics and Development Studies, 2, 8.

[20] Swenson, D. L. (2004). Foreign investment and the mediation of trade flows. Review of International Economics, 12(4), 609-629.

[21]UNCTAD. (2018). World Investment Report 2018: Investment and New Industrial Policies. UN. https://doi.org/10.18356/ebb78749-en

[22]Zhang, K. H. (2005). How does FDI affect a host country's export performance? The case of China. In International conference of WTO, China and the Asian Economies (pp. 25-26). 